\title{
Новые поступления в коллекцию Музея геологии и минералогии им. И.В. Белькова в 2018 г
}

\section{Сидоров М.Ю., Компанченко А.А., Жихарева Н.Г.}

Геологический институт ФИЦ КНЦ РАН, Anamumbl, sidorov@geoksc.apatity.ru

Аннотация. В статье дается обзор поступлений образцов пород и минералов Кольского региона в Музей ГИ КНЦ РАН им. И.В. Белькова в 2018. Традиционно, в пополнении коллекции Музея, принимали участие не только работники Геологического института, но и сотрудники других организаций, а так же простые граждане, интересующиеся минералогией. В 2018 году основной фонд Музея пополнился на 60 образцов, научно-вспомогательный - на 328 образцов. С учётом, вновь поступивших образцов, основной фонд музея к концу 2018 г. насчитывает 9120 образцов. География поступлений образцов: Хибинский и Ловозёрский щелочный комплексы, Западно-Панский массив, Западные Кейвы, Вороньи тундры, Ковдор, Печенга и др.

Ключевые слова: музей, образцы, минералы, породы, Кольский регион.

\section{New sample intakes of the I.V. Bel'kov's Museum of Geology and Mineralogy in 2018}

\author{
Sidorov M.Yu., Kompanchenko A.A., Zhihareva N.G. \\ Geological institute KSC RAS, Apatity, sidorov@geoksc.apatity.ru
}

\begin{abstract}
The article provides an overview of the receipt of rock and mineral samples from the Kola region in the I.V. Bel'kov's Museum of GI KSC RAS in 2018. Traditionally, not only employees of the Geological Institute, but also employees of other organizations, as well as ordinary citizens took part in replenishing the collection of the Museum. In 2018, the main fund of the Museum was replenished with 60 samples, scientific-auxiliary fund - with 328 samples. Taking into account newly arrived samples, the main fund of the museum by the end of 2018 is 9120 samples. Geography of samples: the Khibiny and Lovozero alkaline complexes, West Pansky massif, Western Keivy, Voronyi tundras, Kovdor, Pechenga and others.
\end{abstract}

Key words: museum, samples, minerals, rocks, Kola region.

\section{Введение}

Начиная с 30-х гг. прошлого года, когда на Хибинской горной станции «Тиетта» был образован первый минералогический Музей, наследником которого по праву считается Музей геологии и минералогии им. И.В. Белькова, его главными задачами была собирательная и экспозиционная работа, изучение и хранение коллекций, просветительская и информационная деятельность, рассказывающая широкой общественности о научных достижениях сотрудников Геологического института. Ежегодно фонды Музея пополняются уникальными и ценными образцами (Борисова и др., 2017; Борисова и др., 2016).

В 2018 году в основном музейном фонде были зарегистрированы 60 новых образцов, из них 35 образцов выставлены в экспозиции музея, 12 образцов пополнили петрографическую коллекцию и 13 образцов отправлены в фонды на хранение. С учётом новых поступлений, в основном фонде Музея к концу 2018 г. хранится 9120 образцов.

Как и в прошлые годы, образцы в Музей поступали из самых разных районов Кольского региона: Хибинский и Ловозёрский щелочные комплексы, Западно-Панский массив, Западные Кейвы, Вороньи тундры, Ковдор, Печенга и др.

География поступлений образцов традиционно крайне широкая: Хибинский и Ловозёрский щелочные комплексы, Западно-Панский массив, Западные Кейвы, Вороньи тундры, Ковдор, Печенга и др.

Коллекция научно-вспомогательного фонда музея в 2018 году пополнилась на 328 образцов: Хибинский массив - 60 обр. (Ю.Л. Войтеховский, В.В. Пуха, В.Л. Семёнов, Г.С. Ильин, Е.В. Персиянов, А.В. Калинин); Ловозёрский массив - 6 обр. (Ю.Л. Войтеховский); Кейвы - 131 обр. 
(Ю.Л. Войтеховский); Ковдорский массив - 2 обр. (Д.В. Жиров, А.А. Завьялов); Вороньи тундры 3 обр. (Ю.Л. Войтеховский, А.В. Волошин); Вуориярви, г. Намаваара - 1 обр. (Ю.Л. Войтеховский); Печенга -6 обр. (Ю.Л. Войтеховский, В.В. Пуха) и Африканда - 8 обр. (И.С. Красоткин). Из старых коллекций музея в научно-вспомогательный фонд приняли 117 образцов с минералами: вадеит, астрофиллит, энигматит (Хибинский массив); уссингит, мурманит (Ловозёрский массив); минерал гр. апатита (штаффелит), допсид, волластонит, (Ковдорский массив).

Минералы, требующие определения, дополнительно изучаются в лаборатории физических методов исследования (ГИ КНЦ РАН) методами рентгено-фазового (аналитики Селиванова Е.А., Глазунова М.Ю.) и рентгено-спектрального (аналитики Базай А.В., Тележкин А.А.) анализов.

\section{Первые находки и редкие минералы}

В 2018 году международной комиссией по новым минералам был утвержден новый минерал - митрофановит $\mathrm{Pt}_{3} \mathrm{Te}_{4}$, открытый сотрудниками Геологического института и названный в честь академика РАН Ф.П. Митрофанова (Subbotin et al., 2018). Минерал открыт в Федорово-Панском массиве, на месторождении Восточное Чуарвы.

Впервые на территории России в Хибинском массиве, в виллиомитовой жиле, был найден хальконатронит $\mathrm{Na}_{2} \mathrm{Cu}\left(\mathrm{CO}_{3}\right)_{2} \times 3 \mathrm{H}_{2} \mathrm{O}$. Минерал образует корочки и примазки зеленоватого цвета на поверхности виллиомита (рис. 1).
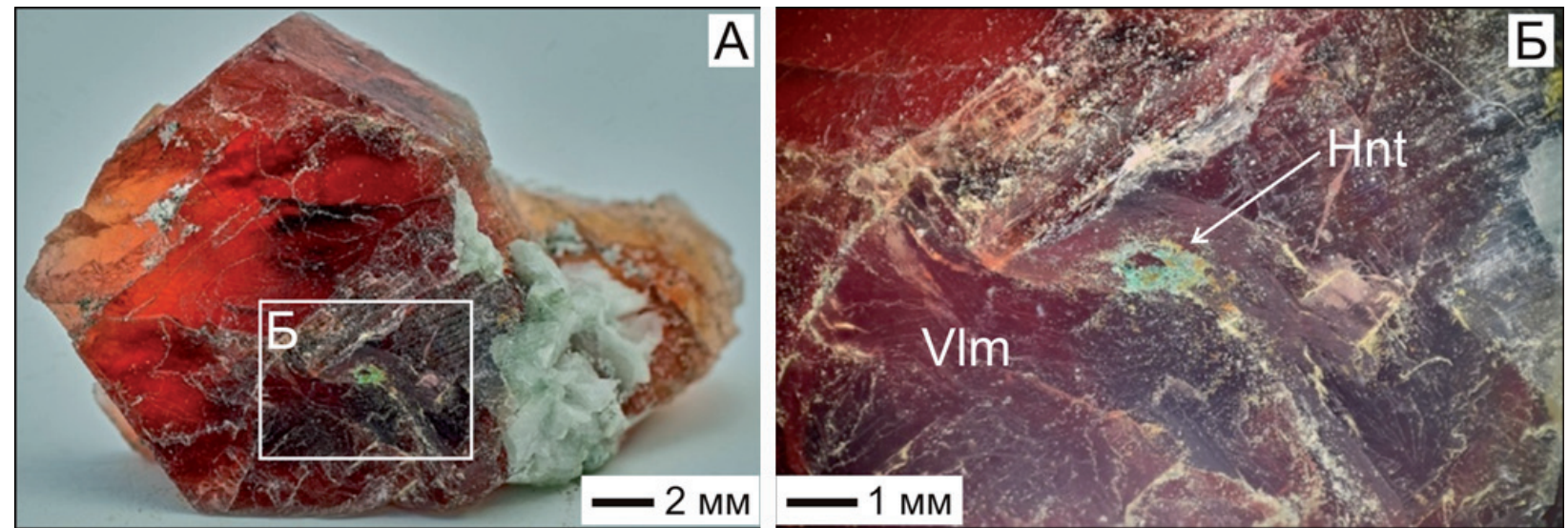

Рис. 1. Хальконатронит (Hnt) на кристалле виллиомита (Vlm). Хибинский массив, г. Кукисвумчорр, Кировский рудник, виллиомитовая жила (ГИМ 7771/1).

Fig. 1. Chalconatronite (Hnt) on villiomite (Vlm) crystal. Khibiny, Kukisvumchorr, villiomite vein (GIM 7771/1).
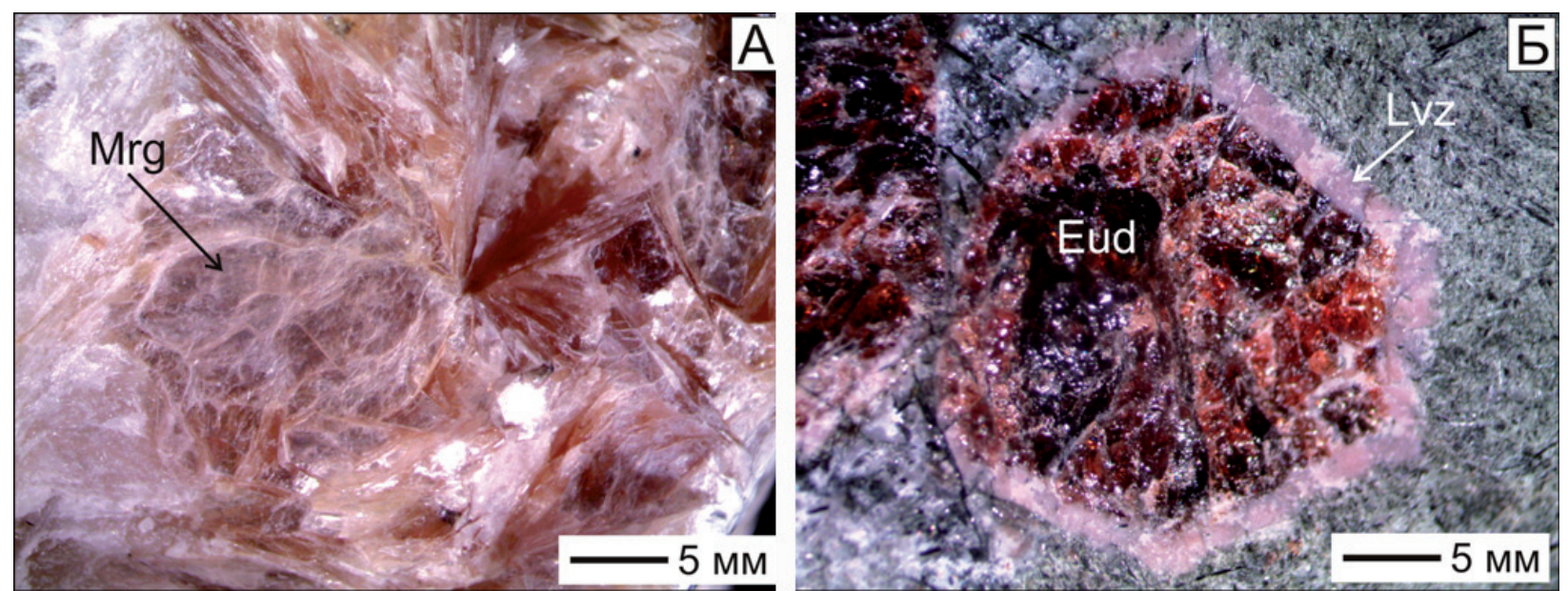

Рис. 2. А - пластинчатые агрегаты маргарита (Mrg), Западные Кейвы, г. Макзабак (ГИМ 7784/2); Б - эвдиалит (Eud) в оторочке ловозерита (Lvz), Ловозёрский массив, г. Аллуайв (ГИМ 7788).

Fig. 2. A - plate aggregate of margarite (Mrg), Western Keivy, Makzabak mt. (GIM 7784/2); Б - eudialite with rim of lovozerite, Lovozero, Alluaiv mt. (GIM 7788). 
К редким и крайне интересным находкам можно отнести образцы с кристаллами ксенотима светло-коричневого цвета, нарастающего на циркон (Западные Кейвы, г. Ровгора, дар Ю.Л. Войтеховского) и розоватые пластинчатые агрегаты маргарита в силлиманите (Западные Кейвы, г. Макзабак, дар Е.Н. Фоминой) (рис. 2).

Впервые в коллекцию музея поступили рустенбургит и винценит (дар Д.А. Габова). Минералы установлены в аншлифе рудного габбро-норита из нижнего расслоенного горизонта уч. Северный Каменник, Западно-Панский массив.

\section{Хибинский щелочной массив}

А.П. Николаевым подарены образцы с мерлиноитом и ханнешитом с г. Коашва и друзы кристаллов натролита, флюорита, эгирина (г. Кукисвумчорр, Кировский рудник, «Натролитовая жила»). Ю.Л. Войтеховский пополнил основной фонд Музея 12-ю образцами. Среди них кристаллы корунда и герцинита в альбите (ручей Свинцовый), пластинчатый кристалл ильменита в натролите (г. Пик Марченко). Также благодаря нему, пополнились коллекции астрофиллита - интересными образцами с волосовидной и радиально-лучистой морфологией (г. Пик Марченко) и лампрофиллита - пластичатые агрегаты (южный склон г. Юкспор). Фрагмент кристалла анальцима передал в Музей Ю.Н. Нерадовский, а кристаллы эвдиалита из пегматита (г. Ньорпахк) - Д.В. Жиров. Интересный образец канкринита (г. Ньорпахк) передал В.Л. Семёнов, а фторапатит жёлтой окраски (г. Кукисвумчорр, Кировский рудник, 209 горизонт) - А.В. Калинин.

\section{Ловозёрский щелочной массив}

В систематическую коллекцию поступили 4 образца. Коллекцию силикатов пополнили образцы с тугтупитом (новый минерал для Кольского региона), лоренценитом, эвдиалитом в оторочке ловозерита (рис. 2), лампрофиллитом с г. Аллуайв (Умбозерский рудник); кузьменкоитом-Мn (новый минерал для Кольского региона) с г. Флора - дар Ю.Л. Войтеховского. При разборе старых коллекций института в основной фонд был принят образец с кристаллами натролита и микроклина (г. Леппхе) из коллекции А.Н. Кулакова.

\section{Другие геологические объекты Кольского региона}

Коллекция минералов Западных Кейв, г. Ровгора из амазонитовых пегматитов пополнилась 13-ю образцами. Наиболее интересны из них образцы циркона в амазоните, кристаллы циркона, касситерит в амазоните, касситерит (фрагмент кристалла), касситерит в кварце, кристаллы ильменита и циркон в кварце передал в фонд музея Ю.Л. Войтеховский. Коллекция Ковдорского массива увеличилась на 3 образца, среди которых наиболее интересен штуф размером $33 \times 21 \times 7$ см с пирротином и халькопиритом в виде крупных гнёзд, до 6-8 см, во флогопит-магнетитовых карбонатитах, образцы с халькопиритом, пиритом, флогопитом - дар Д.В. Жирова, А.А. Завьялова. Пополнилась коллекция минералов пегматитов: образцы с редким минералом гафноном из лепидолитового грейзена редкометальных пегматитов, месторождения Васин-Мыльк передал А.В. Волошин, а кристалл берилла из Шонгуйского месторождения - Ю.Л. Войтеховский.

\section{Петрографическая коллекция}

В петрографической коллекции Музея выставлена экспозиция из 12 новых образцов. Полированные образцы тингуаита с ячеисто-зональной, очковой, полосчатой текстурой дополнили коллекцию тингуаитов и украсили экспозицию щелочных пород Хибинского массива (г. Тахтарвумчорр, г. Тахтампорр, г. Кукисвумчорр, p. Поачйок) - дар В.Л. Семёнова. Тингуаит с полосчатой текстурой (г. Тахтарвумчорр) передал Ю.Л. Войтеховский. В коллекцию Музея из старых коллекций института В.В. Пухой был передан образец вариолитовых базальтов (Печенга, IV вулканогенная толща).

\section{Источники поступлений}

Коллекции музея пополнили сотрудники Геологического института: Ю.Л. Войтеховский, А.В. Волошин, Д.А. Габов, Ю.Н. Нерадовский, Д.В. Жиров, В.В. Пуха, В.Л. Семёнов; Е.Н. Фомина. В дар получены образцы минералов и пород от сотрудников других организаций и частных лиц 
- И.С. Красоткина (пенсионер, г. Кировск), А.П. Николаева (пенсионер, г. Кировск), Г.С. Ильина (м.н.с. ИИЕТ РАН им. Вавилова, г. Москва), А.В. Калинина (геолог Кировского рудника АО «Апатит»), А.А. Завьялова (начальник службы мониторинга устойчивости уступов Ковдорского ГОКа), Е.В. Персиянова (геолог Кировского рудника).

Музей глубоко признателен всем, кто содействовал пополнению музейных фондов и надеется на дальнейшее плодотворное сотрудничество. Фотографии образцов выполнены младшим научным сотрудником ГИ КНЦ РАН А.В. Чернявским.

\section{Литература}

1. Борисова В.В., Волошин А.В., Жихарева Н.Г. Новые поступления в коллекцию Музея геологии и минералогии им. И.В. Белькова Геологического института КНЦ РАН в 2016 // Труды Ферсмановской научной сессии ГИ КНЦ РАН. 2017. № 14. С. 61-64.

2. Борисова В.В., Волошин А.В., Жихарева Н.Г., Чернявский А.В. Новые поступления в коллекцию Музея геологии и минералогии им. И.В. Белькова ГИ КНЦ РАН в 2017 г. // Труды Ферсмановской научной сессии ГИ КНЦ РАН. 2018. № 15. С. 68-72.

3. Subbotin, V.V., Vymazalová, A., Laufek, F., Savchenko, Y.E., Stanley, C.J., Gabov, D.A. and Plášil, J. (2018) Mitrofanovite, IMA 2017-112. CNMNC Newsletter No. 42, April 2018, page 450; Mineralogical Magazine. V. 82. P. $445-451$. 